\title{
NEW RECORDS OF INTERESTING XENOPHYTES IN THE IBERIAN PENINSULA
}

\author{
Filip VERLOOVE ${ }^{1} \&$ Enrique SÁNCHEZ GULLÓN²*
}

\author{
${ }^{1}$ National Botanic Garden of Belgium, Domein van Bouchout, B-1860 Meise, Belgium \\ ${ }^{2}$ Paraje Natural Marismas del Odiel (Huelva), Ctra. del Dique Juan Carlos I, \\ Km 3. Apdo. 720. 21071 Huelva. \\ *Author for correspondence: enrique.sanchez.gullon@juntadeandalucia.es
}

Recibido el 30 de abril de 2008, aceptado para su publicación el 15 de septiembre de 2008 Publicado "on line" en octubre de 2008

\begin{abstract}
New records of interesting xenophytes in the Iberian Peninsula. Botanical inventories in various parts of Spain mainly between 2005 and 2007 yielded numerous chorological novelties. Cyperus prolifer is probably reported for the first time in Europe. Chenopodium simplex, Dactyloctenium aegyptium, Digitaria violascens, Eragrostis frankii, Ipomoea x leucantha, Ludwigia peploides subsp. montevidensis, Malvastrum coromandelianum, Melinis repens subsp. repens, Oenothera indecora subsp. indecora, Panicum philadelphicum subsp. gattingeri and Solanum americanum are probably recorded for the first time from Spain. Crassula campestris is first cited from Portugal. New provincial records include: Abutilon grandifolium (Barcelona), Amaranthus palmeri (Lérida), Amelichloa caudata (Valencia), Anoda cristata (Huelva), Arctotheca calendula (Gerona), Asparagus setaceus (Huelva), Bidens subalternans (Huelva), Cardiospermum halicacabum (Alicante), Cenchrus incertus (Cádiz), Cestrum parqui (Barcelona), Cyperus esculentus (Huelva), Datura ferox (Huelva), Elymus elongatus subsp. ponticus (Lérida, Sevilla), Eragrostis mexicana subsp. virescens (Huelva), Eragrostis pectinacea (Huelva), Galinsoga quadriradiata (Huelva), Hydrocotyle bonariensis (Huelva), Leptochloa uninervia (Granada, Huesca), Oenothera oehlkersi (Gerona), Rumex cristatus (Gerona), Senna obtusifolia (Huelva), Setaria faberi (Huelva), S. parviflora (Huelva), Solanum elaegnifolium (Alicante), S. linnaeanum (Granada), S. physalifolium (Huelva) and Verbena litoralis var. brevibracteata (Huelva). Previous Andalusian records of Galenia secunda turned out to be in error for G. pubescens. A large majority of the cited taxa is of American origin.
\end{abstract}

Key words. New records, Xenophytes, Spain.

RESUMEN. Nuevas citas de xenófitos interesantes en la Península Ibérica. Diferentes campañas de herborizaciones en España entre los años 2005 -2007, han propiciado el descubrimiento de diferentes novedades corológicas para su flora. Se cita como novedad para Europa Cyperus prolifer. Son probablemente nuevas citas para España Chenopodium simplex, Dactyloctenium aegyptium, Digitaria violascens, Eragrostis frankii, Ipomoea x leucantha, Ludwigia peploides subsp. montevidensis, Malvastrum coromandelianum, Melinis repens subsp. repens, Oenothera indecora subsp. indecora, Panicum philadelphicum subsp. gattingeri y Solanum americanum. Se cita como novedad por el Portugal Crassula campestris. Se incluyen como novedades provinciales: Abutilon grandifolium (Barcelona), Amaranthus palmeri (Lérida), Amelichloa caudata (Valencia), Anoda cristata (Huelva), Arctotheca calendula (Gerona), Asparagus setaceus (Huelva), Bidens subalternans (Huelva), Cardiospermum halicacabum (Alicante), Cenchrus incertus (Cádiz), Cestrum parqui (Barcelona), 
Cyperus esculentus (Huelva), Datura ferox (Huelva), Elymus elongatus subsp. ponticus (Lérida, Sevilla), Eragrostis mexicana subsp. virescens (Huelva), Eragrostis pectinacea (Huelva), Galinsoga quadriradiata (Huelva), Hydrocotyle bonariensis (Huelva), Leptochloa uninervia (Granada, Huesca), Oenothera oehlkersi (Gerona), Rumex cristatus (Gerona), Senna obtusifolia (Huelva), Setaria faberi (Huelva), S. parviflora (Huelva), Solanum elaegnifolium (Alicante), S. linnaeanum (Granada), S. physalifolium (Huelva) y Verbena litoralis var. brevibracteata (Huelva). Se actualiza la nomenclatura en Andalucía de las citas previas del taxón Galenia secunda, que se cambia por Galenia pubescens, su nombre correcto. Una gran mayoría de los taxones citados son de origen americano.

Palabras clave. Novedades, Xenofitos, España.

\section{INTRODUCTION}

Studies on alien plants are gaining a lot of attention worldwide since plant invasions are believed to be one of the major reasons for the decrease of biodiversity. As such, information about means and time of introduction, origin, biology, ecology, degree of naturalization is an essential tool for this purpose.

In the past decades the knowledge about non-native plants much increased in the Iberian Peninsula. Sanz Elorza et al.(2004) recently published a detailed account on Spanish xenophytes (emphasizing on invasive species). This catalogue provides up-to-date information on all known Spanish xenophytes and surely is a standard reference with regard to studies on non-native vascular plants in Spain.

However, as a result of ongoing intercontinental trade the number of plant introductions is still increasing today and such catalogues soon become obsolete.

In this paper we present recent records for numerous interesting non-native vascular plants. At least one species is probably reported for the first time in Europe. Several others turned out to be first recorded from either Spain or Portugal and a lot are first provincial records.

The species here dealt with are - some excepted - essentially species that have been introduced unintentionally. In a separate paper, new interesting records of non-native garden escapes will be provided. The degree of naturalization of the taxa here concerned is variable: some are already fully naturalized or even invasive (for instance Ludwigia peploides), others are strictly ephemeral for the time being. Even in the latter case, they are worth mentioning since every occurrence might represent a first step towards a future naturalization.

\section{MATERIALS AND METHODS}

The here presented floristic records are mainly the result of fieldwork in the Iberian Peninsula between 2005 and 2007. However, additional records were obtained from a partial revision of critical specimens from the private herbarium of the second author. Some records therefore date back to 1997.

Voucher specimens of nearly all taxa have been collected. They are preserved in the private collections of the authors (further abbreviated respectively as priv. herb. FV and priv. herb. ESG) and duplicates have been included in the public herbaria of the National Botanic Garden of Belgium (BR), the herbarium of the University of Liège, Belgium (LG), the Real Jardín Botànico de Madrid (MA), the herbarium of the University of Malaga (MGC), the herbarium of the University of Pablo de Olavide, Sevilla (UPOS) and/or the herbarium of the University of Sevilla (SEV). 


\section{RESULTS}

Beneath we present chorological novelties for the Iberian Peninsula. Once again, the prevalence of species of American origin is striking. This has been shown before in Spain, see for instance Masalles et al.(1996), Del Monte \& Aguado (2003) and Bartoli et al.(2007). In table 1 the areas of origin and the xenophyte category according to Kornás (1990) are given.

Abutilon grandifolium (Willd.) Sweet Hort. Britannicus 1: 53 (1826) (Malvaceae)

Often misspelt as Abutilon grandiflorum (see for instance Sanz Elorza et al. 2004).

BARCELONA: El Prat de Llobregat, La Ricarda (SE-side of Aeroport de Barcelona) (UTM 31TDF2572), talus of artificial sandscape, one specimen, 15-IX-2007, F. Verloove 6907 (priv. herb. FV, dupl. MA 764155).

Abutilon grandifolium, a native of South America, is more or less established in the surroundings of Cádiz (Paiva \& Nogueira 1993). It is fully naturalized in the Canary Islands (Hohenester \& Welss, 1993). The present record near Barcelona (probably only ephemeral) apparently is the first for Catalunia (Casasayas i Fornell, 1989).

In Spain Abutilon grandifolium is considered to be an escape from cultivation (Paiva \& Nogueira 1.c.). If so, the species is surprisingly omitted by Le Huquet (1997).

Amaranthus palmeri S. Watson, Proc. Amer. Acad. Arts 12: 274 (1877) (Amaranthaceae)

LÉRIDA: Térmens towards Ménarguens (NE-Lérida), roadverge near Segre-river (UTM 31TBG1321), locally abundant, male and female plants, 10-IX-2007, F. Verloove 6941 (MA 764159).

Amaranthus palmeri, a dioecious amaranth from North America, was known in Spain from a few localities in the provinces of Barcelona and Sevilla (Carretero, 1990). In 2002 the species was recorded again in Fenals (Lloret de Mar; Verloove 2003).

In September 2007 numerous additional records came to light from the surroundings of
Lérida. In addition to the collection referred to above, Amaranthus palmeri has been recorded in the following localities:

VILANOVA DE LA BARCA, C13 towards Lérida, km 13-12 (UTM 31TCG0814), roadverge, one specimen, 11-IX-2007; LÉRIDA (E1 Cappont), Canal de Seros x N240a (UTM 31TBG0309), roadverge, one specimen, 11-IX2007; LÉRIDA towards Alcoletge, C13 (UTM 31TCG0511), roadverge, several specimens, 11IX-2007; ALCOLETGE, C13 x Autovia A2 (UTM 31TCG0612), roadverge, several specimens, 12-IX-2007; LÉRIDA (El Cappont), Canal de Seros close to Cepsa-service station (UTM 31TBG0309), canalbank, locally abundant, 12-IX-2007; LÉRIDA (E1s Mangraners), N240 towards Les Borges Blanques (UTM 31TCG0608), roadverge, two specimens, 14-IX-2007.

The present records from Lérida suggest an ongoing naturalization of Amaranthus palmeri in NE-Spain.

Amelichloa caudata (Trin.) Arriaga \& Barkworth, Sida 22(1): 148 (2006) (syn.: Jarava caudata (Trin.) Peñail., Stipa caudata Trin.) (Poaceae)

VALENCIA: Manises, valley of river Turia, Calle Juan Bta. Miquel Garcera, near airport, +/ruderalized grass- and shrubland near riu Turia, very common locally, 11-IX-2005, F. Verloove 6163 (BR); idem (leg. D. Ortiz), VI-2006, F. Verloove 6419 (priv. herb. FV, dupl. BR, LG); Manises, neglected railway track and adjacent roadverge near airport, 2 specimens, 11-IX-2005, F. Verloove s.c.; GERONA: Costa Brava, Albons (S of L'Escala) (UTM 31TEG0761), grassy talus in village, 5-10 ex., 11-VI-2007, F. Verloove 6838 (BR).

Amelichloa is a recently described segregate of Stipa (Arriaga \& Barkworth 2006). It includes five New World species of which three have recently been recorded as naturalized xenophytes in southern Europe (Amelichloa ambigua (Speg.) Arriaga \& Barkworth, A. brachychaeta (Godr.) Arriaga \& Barkworth and A. caudata; all as representatives of the genus Jarava Ruiz et Pavon, see Verloove 2005b). Amelichloa is distinguished by the sharp tips of its basal leaves, the presence of smooth longitudinal ribs on its 


\begin{tabular}{|c|c|c|}
\hline Name taxon & Origin & Category (sensu Kornás 1990) \\
\hline Abutilon grandifolium & South America & Epoecophyte/Ergasiophygophyte \\
\hline Amaranthus palmeri & North America & Epoecophyte \\
\hline Amelichloa caudata & South America & Epoecophyte \\
\hline Anoda cristata & Central- and South America & Ephemerophyte \\
\hline Arctotheca calendula & South Africa & Holoagriophyte \\
\hline Asparagus setaceus & South Africa & Holoagriophyte \\
\hline Bidens subalternans & South America & Ephemerophyte \\
\hline Cardiospermum halicacabum & Tropics & Ephemerophyte \\
\hline Cenchrus spinifex & Americas & Epoecophyte \\
\hline Cestrum parqui & South America & Ergasiophygophyte \\
\hline Chenopodium pumilio & Australia & Epoecophyte/Holoagriophyte \\
\hline Chenopodium simplex & North America & Ephemerophyte \\
\hline Chloris truncata & Australia & Epoecophyte/Ephemerophyte \\
\hline Chloris virgata & Tropics & Epoecophyte \\
\hline Conyza bilbaoana & South America & Epoecophyte \\
\hline Crassula campestris & South Africa & Epoecophyte \\
\hline Cyperus esculentus & Subtropics & Epoecophyte \\
\hline Cyperus prolifer & East Africa & Ergasiophygophyte \\
\hline Dactyloctenium aegyptium & Old world tropics & Ephemerophyte \\
\hline Datura ferox & East Asia & Ephemerophyte \\
\hline Digitaria violascens & Tropics (As., Am.) & Epoecophyte \\
\hline Elymus elongatus subsp. ponticus & Southeastern Europe & Ergasiophygophyte \\
\hline Eragrostis frankii & North America & Epoecophyte \\
\hline Eragrostis mexicana subsp. virescens & South America & Epoecophyte \\
\hline Eragrostis pectinacea & North America & Epoecophyte \\
\hline Galenia pubescens & South Africa & Epoecophyte \\
\hline Galinsoga quadriradiata & South America & Epoecophyte \\
\hline Hydrocotyle bonariensis & Americas & Ephemerophyte \\
\hline Ipomoea x leucantha & North America & Epoecophyte \\
\hline Leptochloa uninervia & Americas & Holoagriophyte/Epoecophyte \\
\hline \multicolumn{3}{|l|}{ Ludwigia peploides } \\
\hline subsp. montevidensis & South America & Holoagriophyte \\
\hline Malvastrum coromandelianum & South America & Ephemerophyte \\
\hline Melinis repens & Africa, Southwest Asia & Epoecophyte \\
\hline Oenothera indecora & South America & Ephemerophyte \\
\hline Oenothera oehlkersi & Europe & Epoecophyte \\
\hline \multicolumn{3}{|l|}{ Panicum philadelphicum } \\
\hline gattingeri & North America & Holoagriophyte \\
\hline Pteris vittata & Old World tropics & Ergasiophygophyte \\
\hline Rumex cristatus & SE-Europe, SW-Asia & Epoecophyte \\
\hline Senna obtusifolia & Americas & Ephemerophyte \\
\hline Setaria faberi & China & Holoagriophyte \\
\hline Setaria parviflora & South America & Epoecophyte \\
\hline Solanum americanum & Americas & Epoecophyte \\
\hline Solanum elaeagnifolium & South America & Epoecophyte \\
\hline Solanum linnaeanum & South Africa & Epoecophyte \\
\hline Solanum physalifolium & South America & Holoagriophyte \\
\hline Verbena litoralis var. brevibracteata & South America & Ephemerophyte \\
\hline
\end{tabular}

Table 1.: Origin and xenophyte category of several new and other interesting xenophytes in the Iberian Peninsula. Taxa that are native in the Americas are presented in bold face. Origen y categoria de algunos de los nuevos xenófitos citados en la Península Ibérica. Los taxones americanos están representados en negrita. 
caryopses, its persistent stylar base and in the frequent presence of cleistogamous panicles in the axils of its basal leaf sheaths.

Amelichloa caudata, originally native in South America, was known so far from the Spanish provinces of Zaragoza (Pyke 2003), Barcelona and Gerona (Verloove 2005b). It is a fast-spreading xenophyte likely to become a noxious environmental weed. The present records from Valencia (a new provincial record) and Gerona confirm the species' spread in northeastern Spain.

Anoda cristata (L.) Schlecht., Linnaea 11: 210 (1837) (Malvaceae)

HUELVA: Huelva, carretera N442, circunvalación de Huelva-Mazagón (UTM 29SPB2183), ruderal en arcenes de la carretera, 4-1-2007, E. Sánchez Gullón 77 (priv .herb. ESG, dupl. SEV 220613, MGC 67050, MA 762673, $\mathrm{BR})$.

Anoda cristata originates in Mexico and Central-America. In Europe it has been recorded as a regular but ephemeral grain alien, especially as a contaminant in soybeans (see for instance Verloove \& Vandenberghe, 1994). Paiva (1993) did not include Anoda cristata in his treatment of Malvaceae for Flora Iberica. However, Díaz Vargas et al. (1991, sub Anoda hastata Cav.) already provided a record from Malaga province, apparently the first Spanish record. The present record probably is the first in Huelva province. Anoda cristata behaves like an ephemeral alien.

Arctotheca calendula (L.) Levyns, Journ. South Afr. Bot. 8: 284 (1942) (Asteraceae)

GERONA: L'Escala, Montgó (Costa Brava) (UTM 31TEG1462), ruderal sandy area near campsite, few specimens, 11-VI-2007, F. Verloove 6793 (BR).

The South African Arctotheca calendula has become an undesirable environmental weed in parts of the Iberian Peninsula. Especially in parts of Andalucia it penetrates in valuable and vulnerable coastal dunes (Dana \& al. 2005). Elsewhere in Spain, Arctotheca calendula was able to become naturalized in various localities, chiefly in the northern provinces (Sanz Elorza et al.2004).

Along the Mediterranean coast, Arctotheca calendula appears to be much rarer. In Catalonia it was probably not reported prior to 1976 (Sierra i Ràfols, 1979) and up to present it is only known from scattered records in the provinces of Barcelona and Tarragona. In 2007 a small population was seen, apparently for the first time, in the province of Gerona. In this area of Spain, Arctotheca calendula seems to be much less invasive than in Andalucia.

Asparagus setaceus (Kunth) Jessop, Bothalia 9: 51 (1966) (syn.: A. plumosus Baker) (Asparagaceae)

HUELVA: Isla Cristina, Monte Dunas (UTM 29SPB1851), en sotobosque Eucalyptus spec. y Pinus pinea, 15-IX-2006, E. Sánchez Gullón 02 (priv.herb. ESG, dupl. BR).

Asparagus setaceus, a native of South Africa, is much cultivated as an ornamental throughout the Iberian Peninsula (Cullen, 1986, Herrero-Borgoñón et al. 2005). It is readily dispersed by birds and has become naturalized in recent times. There are apparently no previous records from Huelva province. Dana Sánchez \& Sanz Elorza (2008) recently reported about additional new records in Andalucía.

Bidens subalternans DC., Podr. 5: 600 (1836) (Asteraceae)

HUELVA: Huelva, carretera N442, circunvalación de Huelva-Mazagón (UTM 29SPB2383), ruderal en arcenes de la carretera, 4-XI-2007. Sánchez Gullón 83 (priv.herb. ESG, dupl. SEV 220524, BR).

Bidens subalternans is a native of South America (from southernmost Brasil to northern Argentina). It is increasingly naturalized in southern Europe (Tutin, 1976, Bolòs et al., 1990, Masallés et al., 1996, Serra Laliga et al., 1993). In Spain Bidens subalternans is predominantly dispersed in Levante and the northern and northeastern provinces (Sanz $\square$ Elorzæt al. 2004). The present record from Huelva is the first Andalucian one. The species normally sets seed and is likely to become naturalized in man-made habitats.

Bidens subalternans much resembles and is often confused with Bidens bipinnata L. However, it has narrower leaf segments that are 
more or less equally hairy throughout, outer achenes 6-8 mm, inner achenes 8-14 $\mathrm{mm}$ with erect awns, ca. 1-2,5 mm long at maturity (see excellent illustrations in Duvigneaud, 1975).

\section{Cardiospermum halicacabum L.,}

\section{Sp. Pl. 366 (1753) (Sapindaceae)}

ALICANTE: Arenales del Sol towards Santa Pola (Gran Alacant, platja del Carabassí), roadverge, on sewage sludge near the beach, 07IX-2005, F. Verloove 6088 (priv. herb. FV, dupl. BR, MA 749375).

Tropical, weedy Sapindaceae, increasingly found in southern Europe, especially in Spain. Known at least from the following provinces: Almeria (Dana et al. 2001), Barcelona (Casasayas i Fornell, 1982), Castellón (Aparicio Rojo \& Mercé Zamora 2003), Cordoba (Moglia et al. 2001) and Huelva (Sánchez Gullón et al. 2006).

The present record from Arenales del Sol probably is the first one in the province of Alicante. Up to present, Cardiospermum halicacabum usually behaves like an ephemeral xenophyte.

\section{Cenchrus spinifex Cav.,}

Icones 5: 38 (1799) (syn.: C. incertus M.A. Curtis) (Poaceae)

CÁDIZ: El Puerto Santa Maria (Fuentebravia), sandy roadverge at military base, abundant, 08-X-2007, F. Verloove 6993 (priv. herb.-FV).

Cenchrus spinifex, a weedy species from the southern United States and Central and South America, is known to be naturalized and locally invasive in several Spanish localities since the 1970's (Torrella et al., 1974), most however concentrated along the Mediterranean coast. It was recently reported for the first time from Andalucia by Sánchez Gullón et al. (2006), apparently as an ephemeral alien.

Near Rota Cenchrus spinifex grows in abundance in a narrow, sandy strip between the military base and the road towards El Puerto Santa Maria (A491). It is accompanied by other exotics viz Digitaria ciliaris, Oenothera drummondii, Paspalum dilatatum,... Here, it is fully naturalized and possibly initially introduced through military activities (the military base of Rota frequently harbours American troops).
Cestrum parqui L'Hérit., Stirp. Nov. 73 (1788) (Solanaceae)

BARCELONA: El Prat de Llobregat, La Ricarda (SE-side of Aeroport de Barcelona) (UTM 31TDF2472), roadverge (sandy) in former seadunes, one young specimen (subspontaneous), 15-IX-2007, F. Verloove 6906 (MA 764153).

Cestrum parqui, a South American shrub from the Solanaceae family, is increasingly escaping in southern Europe: France (Auriault \& Auriault, 1989, Verloove \& Vandenberghe 2002), Italy (Conti et al. 2005), Portugal (Almeida \& Freitas 2006). In Spain

Cestrum parqui has been reported from at least Almeria (Dana et al. 2001), Huelva (Sánchez Gullón \& Rubio García 2002) and Valencia (Laguna Lumbreras \& Mateo Sanz 2001). The present record from Barcelona province apparently is the first record in Catalonia. Cestrum parqui is considered to be a potentially invasive species in Spain («planta(s) con comportamiento invasor incipiente en España ») (Sanz Elorza et al. 2001).

Chenopodium pumilio R. Br., Prodr. 1: 407 (1810) (syn.: Dysphania pumilio (R. Br.) Mosyakin \& Clemants) (Chenopodiaceae) HUELVA: Matalascañas, Rocio Playa, campsite (UTM 29SQA9816), gravelly soil near the sea, 12-X-2007, F. Verloove 6934 (MA $764150)$.

Already cited by Uotila (1990) from Huelva province but apparently not known so far from the Natural Space Doñana (Valdés et al. 2007).

Chenopodium simplex (Torrey) Raf., Atlantic J. 1: 146 (1832) (syn.: C. gigantospermum Aellen, C. hybridum L. subsp. gigantospermum (Aellen) Hultén) (Chenopodiaceae)

HUELVA: Huelva, carretera N442, circunvalación de Huelva -Mazagón (UTM 29SPB2183), ruderal en arcenes de la carretera, 4-XI.2007, E. Sánchez Gullón 84 (priv. herb. ESG, dupl. BR, SEV 220614).

The North American Chenopodium simplex is here cited for the first time from Spain. It behaves like an ephemeral alien, introduced - like elsewhere in Europe (see for instance Uotila (2001) - with cereals and soybeans. 
Chenopodium simplex is much reminiscent of Eurasian C. hybridum but has nearly smooth seeds (versus deeply pitted seeds) and a different chromosome number.

Chloris truncata R. Br., Prodr. 186 (1810)/ Chloris virgata Sw., Fl. Ind. Occid. 1: 203 (1797) (Poaceae)

TARRAGONA: Cambrils, Barranc de Segures (UTM 31TCF3347), recently disturbed talus and roadverge between barranco and railway track, 10-IX-2005, F. Verloove 6120 (BR) and F. Verloove 6096 (priv. herb. FV, dupl. BR, LG, MA 749367) respectively.

These taxa, of Australian and tropical origin respectively, have been reported before from Cambrils (Vallverdú 2000, Verloove 2005a) but their initial populations were recently destroyed after infrastructural works. In 2005 both were rediscovered in the vicinity, Chloris virgata being predominant.

Conyza bilbaoana J. Rémy, Fl. Chilena 4: 76 (1849) (syn.: C. floribunda Kunth) (Asteraceae)

GUIPÚZCOA: Pasaia, N1 close to the harbour, roadverge, wasteland,..., very common, 10-IX-2007, F. Verloove s.n. (MA 749371).

A poorly understood South American native, surprisingly neglected by Campos Prieto \& Herrera Gallastegui (1997), Del Monte \& Aguado (2003), Sanz Elorza et al. (2004) and many others. This species is widely dispersed in southwestern France (and probably the commonest representative of the genus at present; see for instance Rivière, 1988, Dauphin, 1995). Hence, its presence in neighbouring territories in the Iberian Peninsula (northern Atlantic coast) was expected. Aedo et al. (2001) enumerate numerous records from northwestern Spain but only one from Guipúzcoa (an old citation without herbarium collection). In fact, Conyza bilbaoana is a common weedy species in the Spanish-French border area.

Crassula campestris (Eck1. \& Zeyh.) Endl. ex Walp., Repert. Bot. Syst. 2: 253 (1843) (Crassulaceae) (det. E.J. Clement)

ALGARVE (Portugal): Vilamoura (Cerro da Vila), roman site, +/- bare soil, 14-I-2007, D.J.
Nicolle P07/02 (BR).

Crassula campestris, a tiny South African native, was known so far from scattered localities in northeastern and central Spain (Fernandes, 1997). It was apparently not previously reported from Portugal (see also Almeida \& Freitas 2006).

Cyperus esculentus L., Sp. Pl. 1: 45 (1753) (Cyperaceae)

HUELVA: Matalascañas, Hotel Doñana Blues (UTM 29SQA9717), weed in flowerbed, one specimen, 11-X-2007, F. Verloove s.c.

More or less dispersed throughout the Iberian Peninsula according to Castroviejo (2008) but not previously reported from Huelva province.

Cyperus prolifer Lamarck in J. Lamarck \& J. Poiret, Tabl. Encycl. 1: 147 (1791) (Cyperaceae)

HUELVA: Huelva, Parque de Zafra (UTM 29SPB2581), adventicia en márgenes de estanques, 20 -X -2007, E. Sánchez Gullón 94 (priv.herb. ESG, dupl. priv.herb. FV, SEV 221154, UPOS 3378, MA 762676).

Cyperus prolifer, a native of tropical East Africa, is widely cultivated for ornament (see for instance Walters et al., 1984; sub C. papyrus L. "Nanus", C. isocladus Kunth). As an escape from cultivation it has been reported from the United States (Florida and California) and from the Hawaiian Islands (Carter et al., 1996, Strong \& Wagner,, 1997). Cyperus prolifer has strong rhizomes and reproduces easily (chiefly clonally). As such it could become a noxious environmental weed on pond shores and in marshes in the Mediterranean area.

The present record from Huelva apparently is the first one in Europe.

Dactyloctenium aegyptium (L.) Willd., Enum. Pl. 2: 1029 (1809) (Poaceae)

BARCELONA: Gavámar (Gavá), SBarcelona (UTM 31TDF1769), ruderalized, gravelly seadunes, one specimen, 20-IX-2007, F. Verloove 6903 (priv. herb. FV, dupl. MA 764149).

Dactyloctenium aegyptium, originally native in the Old World (sub-) tropics and at present widely distributed in the Americas as well, is not mentioned by Casasayas i Fornell 
(1989), Sanz Elorza et al. (2004) or Almeida \& Freitas (2006). The present record from Gavámar might be the first recorded from the Iberian Peninsula (ephemeral alien).

Elsewhere in the Mediterranean Dactyloctenium aegyptium is in expansion. It has been recorded several times in Italy, incl. Sicily (Conti et al. 2005, Giardina et al.2007) and increasingly so in Cyprus (Meikle, 1985, Hand 2003) and Morocco (Tanji \& Taleb, 1997).

Datura ferox L., Demonstr. Pl. 6 (1753) (Solanaceae)

HUELVA: Huelva, carretera N442, circunvalación de Huelva-Mazagón (UTM 29SPB2183), ruderal en arcenes de la carretera, 4-XI-2007, E. Sánchez Gullón 71 (priv.herb. ESG, dupl. SEV 220526, 220615, MGC 67023, MA 762677, BR).

Datura ferox, a native of eastern Asia but widely naturalized elsewhere in warm-temperate regions of the world, has been reported from various Spanish localities (Bolòs et al., 1990, Díaz Vargas et al., 1991, Aizpuru et al. 2003, Moragues \& Rita 2005, Dana et al. 2005) but apparently not from Huelva province so far.

Datura ferox probably behaves like an ephemeral alien, introduced with cereals and soybeans.

Digitaria violascens Link, Hort. Berol. 1: 229 (1827) (Poaceae)

LÉRIDA: Balaguer, E-bank of riu Segre (between old and new bridge) (UTM 31TCG1728), lawn, more or less ruderalized (disturbed) and damp, locally abundant, 09-IX2007, F. Verloove 6912 (priv. herb. FV, dupl. MA 764154, BR, LG); BARCELONA: El Prat de Llobregat, Sant Cosme (UTM 31TDF2375), lawn, 15-IX-2007, F. Verloove 7014 (MA 764161); CÁDIZ: Peña del Águila (Rota towards Sanlúcar de Barrameda), along A491 close to its junction with CA6041, irrigated lawn, abundant, weedy, 09-X-2007, F. Verloove 6929 (priv.herb. FV, dupl. priv.herb. ESG, dupl. priv. herb. S. Pyke, MA 764156, BR); HUELVA: Mazagón, Parador Nacional (UTM 29SPB0998), en zonas ajardinadas, 29-XI-2007, E. Sánchez Gullón 31 (priv. herb. ESG, dupl. priv. herb. FV, SEV 222513, MA 762678, MGC 67024).
Digitaria violascens, a native of tropical Asia (and perhaps also tropical America), is reported for the first time from the Iberian Peninsula. It is doubtlessly overlooked and confused with native Digitaria ischaemum (Schreb.) Schreb. ex Muhl. Both are annuals with relatively small spikelets ternately arranged on the rhachis and dark brown upper lemmas at maturity. Diacritic features and ecological preferences of southern European populations (France, Italy) of Digitaria violascens have been critically assessed recently (Verloove 2008a). Digitaria ischaemum and D. violascens are best distinguished as follows:

1. Spikelets usually at least $2 \mathrm{~mm}$ long, rarely shorter. Spikelets usually densely hairy (at least when young) with short, curled hairs, some hairs usually with clavate apices. Inflorescence usually subdigitate with a distinct common axis, racemes usually 2-3(-4), rarely more, spreading horizontally at anthesis (at least the lowermost). Upper glume 3-5 nerved, lower lemma 5(-7) nerved, the nerves unequidistantly spaced D. ischaemum

Spikelets usually shorter than $2 \mathrm{~mm}$, rarely longer $(1,4-2,1 \mathrm{~mm})$. Spikelets usually less hairy (even when young) with longer, straight hairs (hairs with clavate apices absent). Inflorescence usually digitate without or with an indistinct common axis, racemes usually (2)3-7, often long remaining erect during anthesis. Upper glume 3-nerved, lower lemma (5-)7 nerved, the nerves closely and equidistantly spaced ................... D. violascens

In Spain and France Digitaria violascens is a weedy species confined to irrigated lawns. Native Digitaria ischaemum appears to be much rarer and is restricted to siliceous soils (often in habitats devoid of human interaction), or more rarely as a weed of arable land. A better understanding of Digitaria violascens will surely yield additional records in the Iberian Peninsula. A revision of herbarium specimens of (presumably) Digitaria ischaemum by Samuel Pyke confirmed the presence of Digitaria violascens as a lawn weed in the provinces of Barcelona, Tarragona and Zaragoza (pers. comm. 2008).

Digitaria violascens is a rather polymorphic species. With respect to spikelet-size two forms (without further taxonomic recognition) are distinguished: a small-spikeleted form with 
spikelets ca. 1,3-1,5 mm long and a largespikeleted form (including the type) with spikelets ca. 1,8-2,1 mm long. Until recently, in southern Europe only the latter has been recorded (from France, Italy and Spain). However, the former (much more easily distinguished) was collected in the lawn of the Parador Nacional in Mazagón, associated with other (sub-) tropical lawn weeds like Axonopus fissifolius and Kyllinga odorata.

Elymus elongatus (Host) Runemark subsp. ponticus (Podp.) Melderis, Bot. J. Linn. Soc. 76(4): 377 (1978) (syn.: Elymus obtusiflorus (DC.) Conert, Elytrigia pontica (Podp.) Holub., Lophopyrum ponticum (Podp.) A. Löve, Thinopyrum ponticum (Podp.) Barkworth et Dewey, Triticum obtusiflorum DC.) (Poaceae)

LÉRIDA: Albatàrrec towards Lérida, C13 (la Bordeta - els Mangraners) (UTM 31TCG0207 and $31 \mathrm{TCG} 0308$ ), roadverge, very common (sown and escaping), 12-IX-2007, F. Verloove s.c.; SEVILLA: Santiponce (N-Sevilla), drive-in motorway, roadverge, locally (sown and escaping), 14-X-2007, F. Verloove s.c.

Elymus elongatus subsp. ponticus, a native of SE-Europe and adjacent Asia, is increasingly sown for off-ramp stabilization, especially in Central-Europe (see for instance Nowack 2007 for a recent overview). It is usually very persistent and often escapes. In the Iberian Peninsula Elymus elongatus subsp. ponticus apparently is a recent newcomer: Vázquez (1999) was the first to report about its discovery in newly sown roadverges in Badajoz province. The present records are probably the first ones for the provinces of Lérida and Sevilla.

This taxon is possibly much more widespread and perhaps overlooked. It is nicely depicted by Vázquez 1.c. and characterized by its tall, densely caespitose habit (easily reaching 150 $\mathrm{cm}$ ) and spikelets being shorter than the lowermost inflorescence internodes (spikelets not overlapping at base of the inflorescence).

Eragrostis frankii C.A. Mey. ex Steud., Syn. Pl. Glumac. 1: 273 (1854) (Poaceae) (det. conf. H. Scholz)

HUELVA: Moguer, Las Madres (UTM
29SPB1490), arvense en cultivos de regadío, 25 I-1999, E. Sánchez Gullón 59 (priv.herb. ESG, dupl. priv.herb. FV); Moguer - Palos de la Frontera, Parque Natural Laguna de las Madres (UTM 29SPB1490), arvense en cultivos de riego, 6-I-2008, E. Sánchez Gullón 105 (priv.herb. ESG, dupl. BR); idem, 8-I-2008, E. Sánchez Gullón 97, 98, 99 \& 100 (priv.herb. ESG, dupl. priv.herb. FV, BR, LG, MA).

Eragrostis frankii, a North American native, is closely related with E. pectinacea and E. pilosa (Koch, 1972). However, it is readily distinguished in having small spikelets $(1,7-5,6 \mathrm{~mm}$ long) with few florets $(3-6 ; 4$ on average in the collections from Huelva) and a more or less rhombic inflorescence with longest branches in the middle of the inflorescence (not pyramidal). In France Eragrostis frankii has been confused with $E$. virescens as well (Portal 2002). The caryopsis of Eragrostis frankii however lacks the deep ventral groove that is typical of $E$. virescens. Moreover, spikelets of Eragrostis frankii are opaque and lead-coloured while they are more or less hyaline and yellowish-green in E. virescens.

In Europe, Eragrostis frankii seems to be in expansion. It was first recorded from Slovenia (former Yugoslavia) and Italy by Melzer (1988) and has subsequently spread to neighbouring regions. Eragrostis frankii recently also reached southern Germany (Scholz \& Ristow 2005) and might have been overlooked elsewhere. Eragrostis frankii is here reported for the first time in the Iberian Peninsula. It is known at least since 1999 as a weed of arable land (strawberries, citrus-orchards, ...) but remained unidentified so far. By now, it is locally fully naturalized and very abundant

Eragrostis mexicana (Hornem.) Link, Hort. Berol. 1: 190 (1827) subsp. virescens (J. Pres1) S.D. Koch \& Sánchez Vega, Phytologia 58(6): 380 (1985) (Poaceae)

HUELVA: Mazagón, close to the lighthouse (UTM 29SPB9312), plantations, common weed, 10-X-2007, F. Verloove 6937 (MA 764141); Huelva, en aceras c/Pablo Rada (UTM 29SPB2582), 03-III-2008, E. Sánchez Gullón (SEV 222514, dupl. MGC 67026); Isla Christina (Huelva) (UTM 29SPB2052), 8-XII-2007, E. Sánchez Gullón (SEV s.n., MGC 67020); Estero 
Domingo Rubio (UTM 29SPB2088), 15-VI1999, E. Sánchez Gullón (MGC 67035).

The South American Eragrostis mexicana subsp. virescens has much extended its distribution range in parts of southern Europe in the past decades. However, up to present, it was not yet recorded from Huelva province. Its actual abundance - at least in some of its localities suggests that it probably has been overlooked so far.

Eragrostis pectinacea (Michx.) Nees, Fl. Afr. Austr. Ill: 406 (1841) (Poaceae)

HUELVA: Matalascañas, in front of Hotel Doñana Blues (UTM 29SQA9717), sandy ruderalized places (plantations, garden weed,...), very common locally, 11-X-2007, F. Verloove 6994 (priv. herb. FV, dupl. MA 764160); Matalascañas, Rocio Playa (UTM 29SQA9816), campsite, sandy and gravelly places near the sea, locally abundant, 11-X-2007, F. Verloove s.c.; Matalascañas (UTM 29SQA9717), ruderal aceras y jardines, 6-I-2008, E. Sánchez Gullón (priv. herb. ESG, dupl. MA 762679, SEV 222515, MGC 67034).

Eragrostis pectinacea is originally native in North America but nowadays naturalized in Central and South America and parts of Asia and Europe. In Europe

Eragrostis pectinacea is long naturalized and expanding in France and Italy and an ephemeral alien in many other countries (cf. Portal 2002). Apparently very rare and insufficiently known in Spain (mentioned, without further information, by Portal 1.c., Sanz Elorza et al. 2004). Recently reported from Zaragoza by Mateo Sanz \& Pyke (1998) and also known from Pais Vasco (Aizpuru et al. 2003).

Unknown so far from Andalucia (Dana et al. 2005). In Matalascañas well established and possibly overlooked. Eragrostis pectinacea resembles somehow E. virescens. In the latter species grains have a ventral groove that is lacking in E. pectinacea.

Galenia pubescens (Ecklon \& Zeyher) Druce, Rep. Bot. Soc. Exch. Club Brit. Isles4(suppl. 2): 624 (1917) (Aizoaceae)

HUELVA: Huelva, Paraje Natural Marismas del Odiel (UTM 29SPB1684), cuneta carretera espigón, s.d., E. Sánchez Gullón 86 (priv.herb. ESG, dupl. BR); CÁDIZ: Cádiz, at the entrance of the old town, gravelly ruderalized soil near the beach, locally abundant, 08-X-2007, F. Verloove 6932 (priv. herb. FV, dupl. BR, MA 764157).

The collections of the Galenia-species currently naturalized in Andalucia, known as $G$. secunda (L. f.) Sonder in Harvey \& Sonder (see for instance Castroviejo, 1990, Sánchez Gullón \& Rubio García, 1999), have recently been revised by Leuenberger \& Eggli (2002). They belong in fact to a closely related taxon, Galenia pubescens. The latter is characterized by leaves and stems grey-green (vs. grey-white), sparsely and closely appressed hairy with hairs c. 0,5-0,7 $\mathrm{mm}$ (vs. loosely appressed hairy with hairs to 1 $2 \mathrm{~mm}$ ) and flowers white to pink (vs. flowers white to yellow) (see also Verloove 2008b).

The identity of the populations of Galenia from Asturias (prov. Oviedo; see Castroviejo, $1990)$ is also in need of revision.

Galinsoga quadriradiata Ruiz \& Pav., Syst. Veg. Fl. Peruv. Chil. 1: 198 (1798) (syn.: G. ciliata (Raf.) S.F. Blake) (Asteraceae)

HUELVA: Cartaya, Camino del Garranchal (UTM 29SPB2565), arvense en cultivos de regadío, 7-XI -2007, E. Sánchez Gullón 33 (priv.herb. ESG, dupl. SEV 220616, BR); Aljaraque (UTM 29SPB2675), viveros, 6-XII2007, E. Sánchez Gullón 95 (priv.herb. ESG, dupl. MA 762680, MGC 67033).

Galinsoga quadriradiata is a South American xenophyte, naturalized in various parts of Spain (Uribe-Echebarría 2003, Krause \& González-Garzo, 1993, Bujan et al., 1999, Bolòs et al., 1999). Dana et al. (2005) did not mention yet Galinsoga quadriradiata in their catalogue of Andalucian xenophytes. However, Salazar Mendías et al. (2000) already reported about its first discovery in Andalucia (Granada). The present records from Huelva province are the first from Western Andalucia. Galinsoga quadriradiata is a weedy species of arable land, orchards, disturbed soils and other anthropogenous habitats.

Hydrocotyle bonariensis Lam., Encycl. Méth. Bot. 3: 153 (1789) (Apiaceae)

HUELVA: Aljaraque (UTM 29SPB2675), ruderal en arcenes de la carretera en taludes 
irrigados, 4-X -2007, E. Sánchez Gullón 90 (priv.herb. ESG, dupl. priv.herb. FV, SEV 219916, MA 762681, MGC 67031).

Hydrocotyle bonariensis is an aquatic, American xenophyte, naturalized in the northwestern part of the Iberian Peninsula (Amaral Franco, 1971, Medina 2003). The present record from Huelva province is the first for Andalucia. Hydrocotyle bonariensis has the potential to spread fast (stoloniferous growth) and could become an environmental weed.

Ipomoea $\mathbf{x}$ leucantha Jacq., Icon. Rar. 2: t. 318

(1788) (Convolvulaceae) (syn.: I. lacunosa

f. purpurea Fernald; = I. cordatotriloba Dennst. x I. lacunosa L.) (det. conf. D.F. Austin)

HUELVA: Huelva, carretera N442, circunvalación de Huelva-Mazagón (UTM 29SPB2684), ruderal en arcenes de la carretera, 4 y 16-XI -2007, E. Sánchez Gullón 78 (priv.herb. ESG, dupl. priv.herb. FV, SEV 220617, 220618, MGC 67030, MA 762682).

Ipomoea $\mathrm{x}$ leucantha is a little known taxon from the Ipomoea batatas-complex (Austin, 1978). This is a taxonomically difficult group in which introgression often takes place. As a result, specific boundaries have become obscure and identification is sometimes critical. This taxon is a putative hybrid of Ipomoea cordatotriloba (syn.: I. trichocarpa Elliott) and I. lacunosa. Both are originally native in the U.S.A. but have spread in Central and South America. Ipomoea $\mathrm{x}$ leucantha itself is known from Brazil, Ecuador, Mexico, Guatemala, Honduras, Colombia, Venezuela, Hawaii and the Philippines; see Austin, 1978, Austin \& Huáman, 1996) and spreads without its parents. It is a reputed weed and hence likely to occur as an alien outside its original distribution range.

From the Ipomoea batatas-complex at least two species have recently been reported from the Iberian Peninsula: Ipomoea batatas and I. triloba (Silvestre 2004, Guillot Ortiz 2006). The former is rather easily distinguished with its conspicuous corolla (40-70 mm long), non-twining, fleshy stems and the presence of subterranean tubers. However, Ipomoea triloba is much reminiscent of $I$. x leucantha and might be confused. Both are distinguished in the following couplet:
1. Sepals (8-)10-13 mm long, long acuminate at apex. Capsule 7-8 $\mathrm{mm}$ in diameter. Seed ca. 3,6 mm long. Corolla 15-35 mm long. I. $\mathrm{x}$ leucantha

Sepals 7-8(-10) mm long, ovate with abruptly caudate apex. Capsule 5-6 $\mathrm{mm}$ in diameter. Seeds ca. 2,8 mm long. Corolla 18-20 mm long

I. triloba

The plant here concerned recently occurred at several places in the surroundings of Huelva. It is fast spreading and fully naturalized along ruderalized roadverges, especially in port-areas. They probably represent the first naturalized populations in Europe. As a casual alien (often introduced with American soybeans), Ipomoea $\mathrm{x}$ leucantha has been recorded in Belgium (Verloove 2006).

Leptochloa uninervia (J. Presl) Hitchc. \& Chase, Contr. U.S. Natl. Herb. 18(7): 383 (1917) (syn.: Diplachne uninervia (J. Presl) Parodi) (Poaceae)

GRANADA: Salobreña, La Caleta, sugar cane field (irrigated), sea level, locally abundant, 19-IX-2004, F. Verloove 5829 (priv. herb. FV); Salobreña, E of Barranco del Cambrón, roadverge, locally, +/- 50 specimens, 19-IX-2004, F. Verloove 5835 (priv. herb. FV, dupl. BR, MA); LÉRIDA: Lérida, river Segre south of the city, muddy riverbank, 10-IX-2007, F. Verloove 7050 (BR, MA 764163); Aitona, NW of the city, rice fields, 10-IX-2007, F. Verloove 7052 (BR, MA 764162); HUESCA: Fraga, right bank of river Cinca, riverbank, few specimens, 13-IX-2007, F. Verloove 7026 (BR); SEVILLA: Santiponce (NSevilla), along N630 at drive-out Santiponce, gravelly roadverge, locally abundant, 14-X-2007, F. Verloove 7024 (BR); HUELVA: Palos de la Frontera - Moguer, Parque Natural Laguna de las Madres (UTM 29SPB1390), arvense en cultivos de riego, 8-I-2008, E. Sánchez Gullón 101 (priv.herb. ESG, dupl. BR, MGC 67028).

Leptochloa uninervia, a noxious weed of American origin, was first recorded in Spain in 1985 (maize fields in the Pla d'Urgell-area, province of Lérida; Mayoral, 1991). In the following years, the species appeared in several new localities and habitats in the same province and its future expansion was predictable (cf. Recasens \& Conesa, 1995). In southern Spain 
Leptochloa uninervia was discovered in 1988 by Peinado et al. (1990) in the provinces of Sevilla and Cordoba. Subsequently, Del Monte \& Curt (2002) in their account on the presence of the genus Leptochloa in Spain, add the species for the province of Badajoz. In Spain the species inhabits a wide range of habitats: agricultural fields (rice, sugar cane, maize,...), roadverges, riverbanks,...

The above records are probably the first for the provinces of Granada and Huesca and confirm the species' naturalization in the surroundings of Lérida. As a matter of fact, Leptochloa is considered to be a problematic weed in the latter area (comm. J. Recasens \& J. Conesa) but the populations have erroneously been ascribed to $L$. fascicularis. Both species are indeed closely related and perhaps mere infraspecific taxa of one variable taxon, Leptochloa fusca (L.) Kunth (respectively subsp. uninervia (J. Presl) N. Snow and subsp. fascicularis (Lam.) N. Snow; see Snow, 1998). The Spanish collections here concerned (see above) are characterized by uppermost leafblades exceeded by the panicles, mature lemmas lead-coloured and unawned,... and are unequivocally ascribable to Leptochloa uninervia. Leptochloa uninervia is here confirmed from Huelva province as well. Up to present there was still some doubt about the exact identity of the representatives of this genus in Huelva (see for instance Valdés et al. 2007).

Ludwigia peploides (Kunth) P.H. Raven subsp. montevidensis (Spreng.) P.H. Raven, Reinwardtia 6: 395 (1963) (Onagraceae)

BARCELONA: El Prat de Llobregat, right bank of river Llobregat (UTM 31TDF2575), muddy river bank, 15-IX-2007, F. Verloove 6901 (MA 764151); GERONA: La Selva de Mar (Costa Brava), ruisseau à proximité de la plage du village, 31-VIII-1956, J. Duvigneaud s.n. (BR, LG; sub Jussieua repens L. subsp. grandiflora Michx.).

Nieto Feliner (2000) cites three species of Ludwigia in Spain: native L. palustris (L.) Elliott and the xenophytes L. grandiflora (Michx.) Greuter et Burdet and L. repens J.R. Forst. Ludwigia palustris and L. repens, both with opposite leaves and without or with very tiny petals, are easily distinguished. Under the name
"Ludwigia grandiflora" however, two different taxa might have been intermixed in Spain up to present: "true" Ludwigia grandiflora and $L$. peploides. Both are distinguished in the following couplet:

1. Flowering stems and pedicels with patent hairs 1-2 mm long. Petals (12-) $15-23 \mathrm{~mm}$ long. Sepals (persistent on the fruit) up to $18 \mathrm{~mm}$ long. Leaves on flowering stems lanceolate to obovate-lanceolate, dull, 4-12 cm long .....

L. grandiflora

Flowering stems and pedicels with patent hairs 0,5-1 mm long. Petals 10-18 mm long. Sepals (persistent on the fruit) up to $10 \mathrm{~mm}$ long. Leaves on flowering stems obovate-oblong to broadly elliptical-oblong, shiny, 3-6 cm long L. peploides subsp. montevidensis

Ludwigia peploides subsp. montevidensis has been recorded at various localities along river El Llobregat: 1'Hospitalet de Llobregat, Sant Boi de Llobregat and Prat de Llobregat and appears to be well naturalized. It is here cited for the first time from Spain but an old record from La Selva de Mar (see above) suggests that Ludwigia peploides probably has been confused with $L$. grandiflora up to present. The latter was given from Alicante, Barcelona, Gerona, Tarragona and Valencia provinces by Nieto Feliner 1.c., the two present records of $L$. peploides fall within the same distribution range.

The recognition of Ludwigia peploides subsp. montevidensis is important since it is a noxious aquatic weed in riverine vulnerable habitats in southern Europe. Its control and eradication is very time-consuming and expensive (...).

Malvastrum coromandelianum (L.) Garcke, Bonplandia 5: 295 (1857) (Malvaceae)

HUELVA: Huelva, carretera N442, circunvalación de Huelva -Mazagón (UTM 29SPB1884), ruderal en arcenes de la carretera, 16 -XI -2007, E. Sánchez Gullón 72 (priv.herb. ESG, dupl. priv.herb. FV, SEV 220620, MGC 67026, MA 762684).

Malvastrum coromandelianum has become a pantropical weed but is probably originally native in tropical America (Hill, 1982). In Europe it is still rare and perhaps only naturalized in Macaronesia (Hansen \& Sunding, 1985, Greuter 
et al., 1989). It furthermore occurs as a rare ephemeral alien, often associated with birdseed and other grains, for instance in Belgium (Verloove, 1998). Apparently not previously recorded from the Iberian Peninsula (Paiva, 1993). Malvastrum coromandelianum probably is an ephemeral alien, introduced with cereals in the port-area of Huelva.

This species much resembles Sida spinosa in general appearance. However, Malvastrum coromandelianum is readily distinguished by the presence of an epicalyx that is lacking in Sida spinosa.

Melinis repens (Willd.) Zizka subsp. repens, Biblioth. Bot. 138: 55 (1988) (syn.: Rhynchelytrum repens (Willd.) C.E. Hubbard, R. roseum (Nees) Stapf \& C.E. Hubbard, Tricholaena rosea Nees) (Poaceae)

MÁLAGA: Viñuela, Embalse de la Viñuela, A335 towards Vélez Málaga, gravelly roadverge, locally abundant in this area, origin obscure, 15X-2007, F. Verloove 6933 (priv. herb. FV, dupl. BR, MA 764158).

Melinis repens subsp. repens is originally native in large parts of (sub-) tropical and southern Africa and southwest Asia (Zizka, 1988). It became widely established throughout the subtropics, for instance in the southern portion of North America (Wipff 2003) and in Australia (Jacobs \& McClay, 1993). Melinis repens subsp. repens is locally naturalized in Tenerife (Canary Islands; Afonso Lopez \& Wildpret de la Torre, 1976, Scholz, 1977) and often confused with native Tricholaena teneriffae (L. fil.) Link.

In the surroundings of Viñuela and Vélez Málaga Melinis repens subsp. repens is locally very well established along the A335. It often grows in extreme abundance in dry, gravelly roadverges over a distance of $15-20 \mathrm{~km}$. It is probably the first case of naturalization in continental Europe (it has been recorded as an ephemeral wool-alien elsewhere in Europe, for instance in Great Britain; Ryves et al., 1996).

The origin of this population remains obscure. At first sight and in view of its growing conditions (nearly monospecific stands in roadverges), an introduction on purpose for roadside stabilization sounds reasonable. Melinis repens subsp. repens however is an annual (or very short-lived perennial) and hence inappropriate for erosion control or reclamation. On account of its beautiful, colourful inflorescence Melinis repens subsp. repens is sometimes cultivated for ornament (Walters et al., 1984). North American populations are usually considered to be garden-escapes (Wipff 1.c.). It finally is a weedy species, usually confined to anthropogenic habitats (in its area of origin as well as in its secondary area) and thus an accidental introduction is not unlikely as well.

Oenothera indecora Cambess. subsp. indecora, Fl. Bras. Merid. 2: 268 (1830) (Onagraceae) (det. conf. W. Dietrich)

BARCELONA: Castelldefels, Gavámar towards Gavá (UTM 31TDF1769), sandy recently sown roadverge, 12-IX-2005, F. Verloove 6097 (priv. herb. FV, dupl. BR, MA 749363).

Oenothera indecora, native in South America (essentially in Brazil, Uruguay, Argentina and Paraguay), belongs to the subsection Munzia. In the Iberian Peninsula this group is represented by Oenothera affinis, $O$. indecora, O. longiflora and O. stricta (Dietrich 2000). Up to present, Oenothera indecora was only reported from Portugal where it is naturalized in Estremadura (Rostanski, 1991, Dietrich 1.c.). Surprisingly, Rostanski 1.c. cites subsp. bonariensis as well as subsp. indecora (the former being prevalent), whereas Dietrich 1.c. only cites subsp. bonariensis. The subspecies are readily distinguished: specimens of subsp. bonariensis are glabrous to the naked eye whereas subsp. indecora is densely pubescent (Dietrich, 1977).

The present record from the surroundings of Barcelona appears to be the first for Spain and perhaps even the first confirmed record of subsp. indecora for the Iberian Peninsula. Plants were characterized by remarkably oblique stems and small pale yellow, usually cleistogamous flowers (petals ca. $6 \mathrm{~mm}$ ).

Oenothera indecora subsp. indecora is an ephemeral alien in Gavámar: the species apparently disappeared soon after its discovery. However, it is obviously in expansion elsewhere in the Mediterranean region: Raus (2006) recently reports about several Greek records (not 
previously mentioned from Greece).

Oenothera oehlkersi Kappus ex Rosta $\square$ Dski, Feddes Repert. 96: 9 (1985) (Onagraceae) (det. conf. K. Rostanski)

GERONA: Besalu, river Fluvia (near Olot) (UTM 31TDG7572), riverbank, 18-VI-2007, F. Verloove 6791 (MA 764164).

Oenothera oehlkersii, possibly a hybrid of O. glazioviana and O. suaveolens, is insufficiently known in Spain. Dietrich (2000) cites records from Barcelona and Orense provinces. In fact, it closely resembles Oenothera glazioviana (large petals, style conspicuously longer than anthers,...) but sepals and stems are entirely greenish (not striate with red and/or redpunctate).

In Besalu Oenothera oehlkersii was found in relative abundance, along with $O$. glazioviana. To our knowledge, it is the first record in the province of Gerona.

Panicum philadelphicum Bernh. ex Trin. subsp. gattingeri (Nash) Freckmann \& Lelong, Sida 20(1): 172 (2002) (syn.: Panicum gattingeri Nash) (Poaceae)

LÉRIDA: Balaguer, right bank of river Segre, near the old bridge (UTM 31TCG1729), muddy, stony riverbank, 04-IX-2005, F. Verloove 6086 (priv. herb. FV, dupl. BR, LG, MA 749369); Balaguer, left bank of river Segre, close to the new bridge (UTM 31TCG1728), stony riverbank, few specimens, 09-IX-2007, F. Verloove 6916 (BR).

Some specimens of this North American taxon were found on the muddy bank of the Segre river, accompanied by other remarkable xenophytes of various origin (Cyperus glomeratus, C. odoratus, Panicum capillare, $P$. dichotomiflorum,...). In Europe this taxon is chiefly distributed in the Italian-Slovenian boundary area where it is known since the 1980's (see for instance Melzer, 1985), primarily as a maize-field weed. Subsequently Panicum philadelphicum subsp. gattingeri has spread to neighbouring countries. Up to present, it was not known from the Iberian Peninsula but it might have been confused with the similar American species, Panicum capillare. Both share a very diffuse panicle and hairy leaf sheaths but they are easily separated as follows:

1. Panicle usually more than $\Omega$ the total height of the plant. Spikelets usually 2,5-3,5 mm long, sometimes longer .......................... P. capillare

Panicle usually (much) less than $\Omega$ the total height of the plant. Spikelets always smaller, usually 1,9-2,4 mm long...

P. philadelphicum subsp. gattingeri

Panicum philadelphicum subsp. gattingeri should be looked for elsewhere in the surroundings of Balaguer. Its presence can be expected in the many maize-growing areas around.

Pteris vittata L., Sp. Pl.: 1074 (1753) (Pteridaceae)

BARCELONA: Gavámar (Gavá), SBarcelona (UTM 31TDF1869), NE-exposed old wall of garden in pinewood, one clump, 19-IX2007, F. Verloove 6904 (priv. herb. FV, dupl. MA 764152).

Pteris vittata is widely distributed throughout the subtropics but perhaps only native in the Old World. According to Nogueira (1986) it is native in Spain in Andalucia, Mallorca and Levante. Further north Pteris vittata rarely occurs as an escape from cultivation. From the surroundings of Barcelona there is a least one previous record (Mataró; Montserrat Recoder, 1982). The present record from Gavámar, on a garden wall, should be regarded as a gardenescape as well.

Rumex cristatus DC., Cat. Pl. Hort. Monsp.: 139 (1813) (Polygonaceae)

GERONA: Begur (Costa Brava) (UTM 31TEG1945), ruderalized beach, 5 ex., 15-VI2007, F. Verloove 6823 (priv. herb. FV, dupl. BR); Pals (Costa Brava) (UTM 31TEG1749), ruderalized beach, 5 ex., 16-VI-2007, F. Verloove 6824 (BR).

Rumex cristatus, a native of southeastern Europe and adjacent Asia, is a fast spreading xenophyte elsewhere in Europe. In Spain López (1987) was the first to cite Rumex cristatus ("en franca expansión, en gran parte del centro de la Península Ibérica"). Subsequently, it was able to further extend its distribution area and a recent 
overview was provided by Quesada et al.(2007). The records above apparently represent the first ones for the province of Gerona and confirm the species spread in northeastern Spain (see also Pino, 1998).

Senna obtusifolia (L.) Irwin \& Barneby, Mem. New York Bot.

Gard. 35: 252 (1982) (syn.: Cassia obtusifolia L.) (Caesalpiniaceae)

HUELVA: Huelva, carretera N442, circunvalación de Huelva-Mazagón (UTM 29SPB2183), ruderal en arcenes de la carretera, 4-XI-2007, E. Sánchez Gullón 79 (priv.herb. ESG, dupl. priv.herb. FV, SEV 220520).

Senna obtusifolia is a xenophyte, native in the New World (sub-) tropics. In Europe it is increasingly found as an impurity in soybeans (see for instance Verloove \& Vandenberghe, 1993 ) but always remains strictly ephemeral and usually even fails to flower. In Spain Senna obtusifolia has been recorded once before, as an ephemeral weed of irrigated crops near Lérida (Recasens \& Conesa, 1995; sub Cassia obtusifolia). In Huelva Senna obtusifolia flowers and fruits well but its presence along roadverges in port-areas is nevertheless probably ephemeral

Setaria faberi R.A.W. Herrmann, Beitr. Biol. Pflanzen 10(1): 51 (1910) (Poaceae)

HUELVA: Hinojales, ribera de Hinojales (UTM 29SQC0409), orilla ribera, 11-X-1997, E. Sánchez Gullón 44 (priv. herb. ESG, dupl. BR).

Setaria faberi is originally native in China but was probably introduced in Europe as a contaminant in cereals from its secondary distribution range in the United States (where it is considered a noxious agricultural weed). Known in the Iberian Peninsula since 1986, apparently only from the northwestern regions: Galicia (Izco \& Amigo, 1986, Amigo et al., 1991) and País Vasco (Campos Prieto \& Herrera Gallastegui 2000). The above record seems to be the first for Huelva province.

This species is much reminiscent of Setaria viridis and S. italica. However, the combination of the following diacritic features easily distinguish it from both: long pilose leafblades, panicle nodding from the base at maturity, finely rugose upper lemma and upper glume ca. æ as long as spikelet length. Setaria faberi is possibly overlooked in Spain.

Setaria parviflora (Poiret) Kerguélen, Lejeunia N.S. 120: 161 (1987) (Poaceae)

HUELVA: Ayamonte (UTM 29SPB2043), bordes de salinas tradicional, 21-VIII-1998, E. Sánchez Gullón 44 (priv. herb. ESG, dupl. BR); Lepe, Cañada de Adrian (UTM 29SPB2852), arvense en cultivos de cítricos, 12-IX-1999, E. Sánchez Gullón 44 (priv. herb. ESG, dupl. BR).

Setaria parviflora has become a more or less widespread South American xenophyte in large parts of the Iberian Peninsula (see for instance Almeida, 1999) but, surprisingly, not yet recorded from Huelva province. The above records have been confused with Setaria pumila and $S$. parviflora might have been widely overlooked. Both are indeed superficially similar but are are easily distinghuished in the following couplet:

1. Annual grasses. Spikelets 3-3,4 mm long. Inflorescence rather stout ............... S. pumila

Perennial grasses. Spikelets 2-3 mm long. Inflorescence slender S. parviflora

A better understanding of Setaria parviflora will probably considerably enlarge its currently known distribution area in the Iberian Peninsula.

Solanum americanum Miller, Gard. Dict. ed. 8, $\mathrm{n}^{\circ} 5$ (1768) (Solanaceae)

HUELVA: Huelva, carretera Huelva - San Juan del Puerto (UTM 29SPB2283), ruderal margenes carretera, 10-XII-2007, E. Sánchez Gullón 88 (priv. herb. ESG, dupl. BR, SEV 222518, MA 762686, MGC 67049).

Solanum americanum, the New World counterpart of $S$. nigrum, is probably cited here for the first time in the Iberian Peninsula (although it might have been overlooked so far). Like Anoda cristata, Bidens subalternans, Chenopodium simplex, Datura ferox, Ipomoea lacunosa, Malvastrum coromandelianum, Senna obtusifolia and many others it was detected as a roadside-weed near port-areas in or near Huelva. Their appearance is surely associated with grain importation (especially soybeans) from the Americas since all are reputed weeds in their area of origin and grain aliens in Europe and 
elsewhere.

Solanum americanum is very similar to $S$. nigrum and both are possibly confused. Its occurrence as a weed is very likely in the Iberian Peninsula. The two species are distinguished as follows:

1. Anthers usually less than $2 \mathrm{~mm}$ long. Corolla often suffused with purple. Sclerotic granules (stone cells) present, usually 1-4. Berry shiny, to $9 \mathrm{~mm}$ in diameter. Inflorescence usually an umbel S. americanum

Anthers usually more than $2 \mathrm{~mm}$ long. Corolla white. Sclerotic granules absent. Berry dull, to $12 \mathrm{~mm}$ in diameter. Inflorescence usually a raceme S. nigrum

Solanum elaeagnifolium Cav., Icon. Descr. 3: 22 (1795) (Solanaceae)

ALICANTE: Guardamar del Segura (N), La Marina, along N332, dry gravelly roadverge, one specimen, 6-IX-2005, F. Verloove 6109 (BR).

Solanum elaeagnifolium - of South American origin - is a fast-spreading, locally noxious environmental weed in the Mediterranean region. In the Iberian Peninsula it is still rare but more or less widely dispersed, especially in coastal areas. However, there are apparently no previous records for Alicante province.

Solanum linnaeanum Hepper \& P.-M.L. Jaeger, Kew Bull. 41: 435 (1986) (Solanaceae)

GRANADA: Salobreña towards Almuñecar, barranco del Cambrón, dry riverbed, nitrophilous vegetation, several specimens,, 19-IX-2004, F. Verloove 5830 (priv. herb. FV).

According to Valdés (1987) widely distributed in western Andalucia but apparently not known from Granada province (eastern Andalucia) so far.

Solanum physalifolium Rusby, Mem. Torrey Bot. Club. 6: 88 (1896) (Solanaceae)

HUELVA: El Granado, Puerto de la Laja (UTM 29SPB5433), ruderal en orillas río Guadiana, s.d., E. Sánchez Gullón 89 (priv. herb. ESG, dupl. BR).

Sobrino \& Del Monte (1992) reported about the presence of the South American Solanum physalifolium in Spain. It was subsequently recorded from the Spanish provinces of Asturias, Madrid, Palencia, Salamanca, Segova, Soria and Zamora, chiefly as a fast spreading noxious weed of arable land (see Sanz Elorza et al. 2002 for an overview).

So far, however, Solanum physalifolium was not yet reported from Andalucia, although it might have passed undetected.

Verbena litoralis Kunth var. brevibracteata (Kuntze) N. O’Leary, Ann. Missouri Bot. Gard. 94: 598 (2007) (syn.: V. litoralis var. brasiliensis '(Vell.) Munir, V. brasilienis Vell.) (Verbenaceae)

HUELVA: Huelva, carretera N442, circunvalación de Huelva -San Juan del Pto. (UTM 29SPB3088), ruderal en arcenes de la carretera, 4-IX-2002, E. Sánchez Gullón 96 (priv.herb. ESG, dupl. COA).

Verbena litoralis var. brevibracteata is originally native in South America but has become widespread in many warm-temperate and subtropical regions of the world. In the Iberian Peninsula it is predominantly represented in the northeastern portion (Verloove 2003, Pujadas Salvà \& Plaza 2008). In Huelva, Verbena litoralis var. brevibracteata probably rather behaves like an ephemeral alien in nitrophilous man-made habitats.

O'Leary et al. (2007) pointed out that the correct name at varietal rank for this taxon is Verbena litoralis var. brevibracteata.

ACKNOWLEDGEMENTS. Daniel Austin (Tucson, USA), Werner Dietrich (Düsseldorf, Germany), Krzysztof Rostanski (Katowice, Poland) and Hildemar Scholz (Berlin, Germany) are thankful for the confirmation of some of our determinations. We thank Eric Clement for providing the first Portuguese record of Crassula campestris.

\section{BIBLIOGRAPHY}

AEDO, C., J.J. ALDASORO, J.M. ARGÜELLES,

L. CARLÓN, A. DÍEZ RIOL, G. GÓMEZ CASARES, J.M. GONZÁLEZ DEL VALLE, A. GUILLÉN OTERINO, M. LAÍNZ, G. MORENO MORAL, J. PATALLO \& O. SÁNCHEZ PEDRAJA -2001- 
Contribuciones al conocimiento de la flora Cantábrica. Bol. Cien. Nat. R.I.DE.A. 47: 7 52.

AFONSO LOPEZ, R. \& W. WILDPRET DE LA TORRE -1976- Rhynchelytrum repens (Willd.) C.E. Hubb. y Elymus caput-medusae L., dos adiciones al catálogo florístico del Archipiélago Canario. Vieraea 6(1): 121-138.

AIZPURU, I. et al. -2003-Claves ilustradas de la Flora del Pais Vasco y territorios limitrofes. Eusko Jaurlaritza -Gobierno Vasco: $831 \mathrm{p}$.

ALMEIDA, J.D. \& H. FREITAS -2006- Exotic naturalized flora of continental Portugal - a reassessment. Bot. Complutensis 30: 117-130.

ALMEIDA, J.D. -1999- Flora exótica subespontânea de Portugal continental (Plantas vasculares), $2 \mathrm{e}$ ed. Universidade de Coimbra, Coimbra: $153 \mathrm{p}$.

AMIGO, J., M. BUJAN \& I. ROMERO -1991Révision taxonomique du genre Setaria (Gramineae) dans la Péninsule Ibérique. Bull. Soc. Bot. Fr. 138, Lettres bot. (2): 155-165.

APARICIO ROJO, J.M. \& J.M. MERCÉ ZAMORA -2003-Aportaciones a la flora de la provincia de Castellón, II. Toll Negre 2: 19-23.

ARRIAGA, M.O. \& M.E. BARKWORTH 2006-Amelichloa: a new genus in the Stipeae (Poaceae). Sida 22(1): 145-149.

AURIAULT, M. \& R. AURIAULT -1989Cestrum parqui L'Hér., adventice dans l'Hérault. Le Monde des Plantes 435: 27.

AUSTIN, D.F. -1978- The Ipomoea batatas complex - I. Taxonomy. Bull. Torrey Bot. Club 105(2): 114-129.

AUSTIN, D.F. \& Z. HUÁMAN -1996- A synopsis of Ipomoea (Convolvulaceae) in the Americas. Taxon 45: 3-38.

BARTOLI, A., E. SÁNCHEZ GULLÓN, P. WEICKERT \& R.D. TORTOSA -2007Plantas americanas nuevas para la flora adventicia del sur de España. Acta Bot. Malacitana 32: 1-6.

BOLÒS, O., J. VIGO, R.M. MASALLES \& J.M. NINOT -1990- Flora manual dels Paisos Catalans. Ed. Pòrtic, Barcelona.

BUJAN, M., M.I. ROMERO, J. CREMADES \& J. AMIGO - 1999- Sobre la flora alóctona del Noroeste peninsular.'Anales Jard. Bot.
Madrid 45(2): 547 -571.

CAMPOS PRIETO, J.A. \& M. HERRERA GALLASTEGUI -1997- La flora introducida en el País Vasco. Itinera Geobotanica 10: 235-255.

CAMPOS PRIETO, J.A. \& M. HERRERA GALLASTEGUI -2000- Datos sobre flora introducida en el País Vasco. Anales Jard. Bot. Madrid 57(2): 437-441.

CARRETERO, J.L. -1990- Amaranthus. In: Castroviejo, S. et al. (eds.), Flora Iberica, vol. II: Platanaceae-Plumbaginaceae (partim). Real Jardín Botánico, CSIC, Madrid: 559569.

CARTER, R., R.L. MEARS, K. GRADDECK BURKS \& C.T. BRYSON -1996- A report of four exotic Cyperus (Cyperaceae) species new to Florida, U.S.A. Sida 17(1): $275 \square 280$.

CASASAYAS I FORNELL, T. -1982Aportacions a la flora exòtica catalana, I. Fol. Bot. Misc. 3: 73-79.

CASASAYAS I FORNELL, T. -1989- La flora al-loctona de Catalunya. Tesis doctoral. Barcelona: $880 \mathrm{p}$.

CASTROVIEJO, S. -1990- Galenia. In: Castroviejo, S. et al. (eds.), Flora Iberica, vol. II: Platanaceae-Plumbaginaceae (partim). Real Jardín Botánico, CSIC, Madrid: 76.

CASTROVIEJO, S. -2008-Cyperus. In: Castroviejo, S. et al. (eds.), Flora Iberica, vol. XVIII. Real Jardín Botánico, CSIC, Madrid (in press).

CONTI, F., G. ABBATE, A. ALESSANDRINI \& C. BLASI (eds.) -2005-An annotated checklist of the Italian vascular flora. Palombi Editori, Roma: 420 p.

CULLEN, J. -1986-Asparagus. In: Walters, S.M. et al. (eds.), The European Garden Flora. Volume 1. Cambridge University Press: 260263.

DANA, E., M.I. CERRILLO, M. SANZ ELORZA, E. SOBRINO \& J.F. MOTA 2001- Contribución al conocimiento de las xenófitas en España: catálogo provisional de la flora alóctona de Almería. Acta Bot. Malacitana 26: 264-276.

DANA, E.D. \& M. SANZ-2008- Localizaciones de especies alóctonas ornamentales asilvestradas en Andalucía. Bouteloua 3: 1422. 
DANA, E.D., M. SANZ, S. VIVAS \& E. SOBRINO -2005-Especies vegetales invasoras en Andalucía. Dirección General de la Red de Espacios Naturales Protegidos y Servicios Ambientales: 233 p.

DAUPHIN, P. -1995- Sur l'expansion de Conyza floribunda en Gironde. Bull. Soc. Linn. Bordeaux 23(2): 77-78.

DEL MONTE, J.P. \& P.L. AGUADO -2003Survey of the non-native plant species in the Spanish Iberia in the period 1975-2002. Flora Medit. 13: 241-259.

DEL MONTE, J.P. \& M.D. CURT -2002Introduction of species associated with crops: the case of genera Amsinckia and Leptochloa in Spain. Fl. Medit. 12: 341-351.

DÍAZ VARGAS, E., J.M. ESPINOSA GENTO, C. FERNÁNDEZ LÓPEZ, J.C. HERVAS SERRANO \& M. LÓPEZ PULIDO -1991Plantas vasculares de Andalucia Oriental en los ficheros de siete herbarios. Facultad de Ciencias Experimentales, Jaén: 7.

DIETRICH, W. -1977- The South American species of Oenothera sect. Oenothera (Raimannia, Renneria; Onagraceae). Ann. Missouri Bot. Gard. 64: 425-626.

DIETRICH, W. -2000- Oenothera. In: Castroviejo, S. et al. (eds.), Flora Iberica, vol. VIII: Haloragaceae-Euphorbiaceae. Real Jardín Botánico, CSIC, Madrid: 90-100.

DUVIGNEAUD, J. -1975- Une espèce nouvelle pour la flore belge: Bidens subalternans DC. Bull. Soc. Roy. Bot. Belg. 108: 203-207.

FERNANDES, R.B. -1997-Crassula. In: Castroviejo, S. et al. (eds.), Flora Iberica, vol. V: Ebenaceae-Saxifragaceae. Real Jardín Botánico, CSIC, Madrid: 99-103.

FRANCO, J.A. -1971- Nova flora de Portugal (Continente e Açores), vol. 1. Lycopodiaceae -Umbeliferae. Sociedade Astória, Lda. Lisboa: $504 \mathrm{p}$.

GIARDINA, G., F.M. RAIMONDO \& V. SPADARO -2007-A catalogue of plants growing in Sicily. Bocconea 20: 5-582.

GREUTER, W., H.M. BURDET \& G. LONG 1989-Med-Checklist, vol. 4. Dicotyledones (Lauraceae-Rhamnaceae). Conservatoire et Jardin Botanique de la ville de Genève Botanischer Garten und Botanisches Museum Berlin-Dahlem, Geneva-Berlin: 239 p.
GUILLOT ORTIZ, D. -2006- Ipomoea nil (L.) Roth e I. hederacea (L.) Jacquin, dos especies invasoras para la flora valenciana. Acta Bot. Malacitana 31: 153-156.

HAND, R. -2003- Supplementary notes to the flora of Cyprus III. Willdenowia 33: 305-325.

HANSEN, A. \& P. SUNDING -1985- Flora Macaronesica. Checklist of vascular plants. Somerfeltia 1: $167 \mathrm{p}$.

HERRERO -BORGOÑÓN, J.L., P.P. FERRER \& M. GUARA -2005- Notas sobre la flora alóctona valenciana de origen ornamental. Acta Bot. Malacitana 30: 182 -187.

HILL, S.R. -1982- A monograph of the genus Malvastrum - III. Rhodora 84: 317-409.

HOHENESTER, A. \& W. WELSS -1993Exkursionsflora für die Kanarischen Inseln. Verlag Eugen Ulmer, Stuttgart: 374 p.

IZCO, J. \& J. AMIGO -1986- Notas sobre la flora gallega, IV. Trab. Compost. Biol. 13: 127-138.

JACOBS, S.W.L. \& K.L McCLAY -1993Melinis. In: Harden, G.J. (ed.), Flora of New South Wales, vol. IV. Royal Botanic Garden, Sydney: 492.

KOCH, S.D. -1972- The Eragrostis pectinaceapilosa complex in North and Central America (Gramineae: Eragrostoideae). Rhodora 74: 170, 161-219.

KORNÁS, J. -1990- Plant invasions in Central Europe: historical and ecological aspects. In: di Castri F., A.J. Hansen \& M. Debussche (eds.), Biological invasions in Europe and the Mediterranean Basin. Kluwer Academic Publishers, Dordrecht: 19-36.

KRAUSE, A. \& A.M. GONZÁLEZ GARZO 1993- Plantas silvestres de Castilla y León (Escrofulariáceas -Gramíneas). Junta de Castilla y León. Consejería de Cultura y Turismo: $836 \mathrm{p}$.

LAGUNA LUMBRERAS, E. \& G. MATEO SANZ -2001- Observaciones sobre la flora alóctona valenciana. Flora Montiberica 18: 40-44.

LE HUQUET, J.A. -1997-Abutilon. In: Walters, S.M., A. Brady, C.D. Brickell, J. Cullen, P.S. Green, J. Lewis, V.A. Matthews, D.A. Webb, P.F. Yeo \& J.C.M. Alexander (eds.), The European Garden Flora. Volume 5. Cambridge University Press: 221-222.

LEUENBERGER, B.E. \& U. EGGLI -2002- 
Galenia pubescens (Aizoaceae), new to the South American flora. Bot. Jahrb. Syst. 123(4): 441-445.

LÓPEZ, G. -1987- Notas referentes al género Rumex. Anales Jard. Bot. Madrid 44: 580591.

MASALLES, R., F. XAVIER \& J. PINA -1996Flora aloctona de origen americano en los cultivos de Cataluña. Anales Jard. Bot. Madrid 54: 436 -442.

MATEO SANZ, G. \& S. PYKE -1998Aportaciones a la flora Cesaraugustana. Flora Montiberica 9: 37-40.

MAYORAL, A. -1991- Notes florístiques de la Plana d'Urgell, III. Ilerda "Ciències " 49: 79-81.

MEDINA, L. -2003-Hydrocotyle. In: Nieto Feliner, G. et al. (eds.), Flora Iberica, vol. X: Araliaceae-Umbelliferaea. Real Jardín Botánico, CSIC, Madrid: 24-28.

MEIKLE, R.D. -1985-Flora of Cyprus, vol. II. Bentham-Moxon Trust, Kew: 1136 p.

MELZER, H. -1985- Beiträge zur Flora von Friaul-Julisch Venetien und angrenzender Gebiete (Italien, Jugoslawien). Gortania 6: 175-190

MELZER, H. -1988- Über Eragrostis frankii C.A. Meyer ex Steudel, Polygonum pensylvanicum L. und weitere Pflanzenfunde in Friaul-Julisch Venetien (Italien). Linzer biol. Beitr. 20(2): 771-777.

MOGLIA, M.M., J.M. DELGADO MARZO, A. SÁNCHEZ ALMENDRO \& J.M. MUÑOZ ÁLVAREZ -2001- Flora de interés corológico para Andalucía occidental. Acta Bot. Malacitana 26: 260-263.

MONTSERRAT RECODER, P. -1982Comentarios sobre las investigaciones pteridológicas en España. 2a parte. Collect. Bot. 13: 67-84.

MORRAGES, E. \& J. RITA -2005-El vegetals introduits a les Illes Balears. Govern de les Illes Ballears. Conselleria de Medi Ambient: $126 \mathrm{p}$.

NIETO FELINER, G. -2000- Ludwigia. In: Castroviejo, S. et al. (eds.), Flora Iberica, vol. VIII: Haloragaceae-Euphorbiaceae. Real Jardín Botánico, CSIC, Madrid: 87-90.

NOGUEIRA, I. -1986- Pteris. In: Castroviejo, S. et al. (eds.), Flora Iberica, vol. II:
Lycopodiaceae-Papaveraceae. Real Jardín Botánico, CSIC, Madrid: 57-60.

NOWACK, R. -2007- Zur Verbreitung von Elymus obtusiflorus (DC) Conert an Fernstrassen. Flor. Rundbr. 40: 7-8.

O'LEARY, N., M.E. MÚlguRA \& O. MORRONE'-2007-Revisión taxonómica de las especies del género Verbena (Verbenaceae): serie Pachystachyae. Ann. Missouri Bot. Gard. 94: 571-622.

PAIVA, J. -1993-Malvaceae. In: Castroviejo, S. et al. (eds.), Flora Iberica, vol. III: Haloragaceae-Euphorbiaceae. Real Jardín Botánico, CSIC, Madrid: 190-243.

PAIVA, J. \& I. NOGUEIRA-1993-Abutilon. In: Castroviejo, S. et al. (eds.), Flora Iberica, vol. III: Haloragaceae-Euphorbiaceae. Real Jardín Botánico, CSIC, Madrid: 201-203.

PEINADO, M., J.M. MARTINEZ PARRAS, C. BARTOLOMÉ, J. ÁLVAREZ \& M. DE LA CRUZ -1990- Nuevas plantas y nuevas áreas para la Flora de Andalucía Occidental. Lagascalia 16: 125-129.

PINO, J. -1998- Rumex cristatus DC. (Polygonaceae) en Cataluña. Anales Jard. Bot. Madrid 56: 368-369.

PORTAL, R. -2002-Eragrostis de France et de l'Europe occidentale. Vals-près-Le Puy: 431 p.

PUJADAS SALVÁ, A.J. \& L. PLAZA'-2008Verbena. In: Castroviejo, S. (ed.), Flora Iberica, vol. XII (in press).

PYKE, S. -2003- Stipa caudata Trin. en la Peninsula Ibérica. Fl. Montiberica 23: 20-22.

QUESADA, J., C. SALAZAR \& J. PASTOR 2007- Notas taxonómicas y corológicas para la flora de la Península Ibérica. 135. Rumex cristatus DC. (Polygonaceae) especie exótica en Andalucía (S. España). Lagascalia 27: 416-418.

RAUS, T. -2006- Oenothera indecora subsp. indecora. In: Greuter, W. \& T. Raus (eds.), Med-Checklist Notulae, 24. Willdenowia 36: 724-725.

RECASENS, J. \& J.A. CONESA-1995-Nuevas malas hierbas alóctonas en los cultivos de regadio de Cataluña. Actas congreso 1995 de la Sociedad Española de Malherbologia: 5965.

RIVIÈRE, G. -1988- Sur quelques composées 
adventices de Bretagne (genres Bidens L. et Conyza Less.). Le Monde des Plantes 427428: $1-5$.

ROSTANSKI, K. -1991- The representatives of the genus Oenothera L. in Portugal. Bol. Soc. Brot. 64: 5-33.

RYVES, T.B., E.J. CLEMENT \& M.C. FOSTER -1996-Alien grasses of the British Isles. BSBI, London: XX + $181 \mathrm{p}$.

SALAZAR MENDÍAS, C., E. ARROJO AGUDO, J.A. TORRES, A. GARCÍA FUENTES \& F. VALLE TENDERO -2000Algunos elementos de interés en la flora edafófila de la provincia de Granada (S de España). Acta Bot. Malacitana 25: 240 -243.

SÁNCHEZ GULLÓN, E., F.J. MACÍASFUENTES \& P. WEICKERT -2006-Algunas especies adventicias o naturalizadas en la provincia de Huelva (SO de España). Lagascalia 26: 180-187.

SÁNCHEZ GULLÓN, E., B. VALDÉS, F.J. MACÍAS-FUENTES \& P. WEICKERT 2006- Notas para la flora de la provincia de Huelva (SO de España). Lagascalia 26: 187196.

SÁNCHEZ GULLÓN, E. \& J.C. RUBIO GARCÍA -1999- Novedades florísticas para el litoral de Huelva y provincia. I. Lagascalia 21(1): 7-16.

SÁNCHEZ GULLÓN, E. \& J.C. RUBIO GARCÍA -2002-Novedades florísticas para el litoral de Huelva y provincia. II. Lagascalia 22: 7-19.

SANZ ELORZA, M., E. DANA \& E. SOBRINO -2001- Aproximación al listado de plantas alóctonas invasoras reales y potenciales en España. Lazaroa 22: 121-131.

SANZ ELORZA, M., E. DANA SÁNCHEZ \& E. SOBRINO VESPERINAS -2002Aportaciones a la flora de la provincia de Segova. Bot. Complutensis 26: 35-46.

SANZ ELORZA, M., E. DANA SÁNCHEZ \& E. SOBRINO VESPERINAS -2004-Atlas de las plantas alóctonas invasoras en España. Dirección General para la Biodiversidad, Madrid: $384 \mathrm{p}$.

SCHOLZ, H. -1977- Beitrag zur Kenntnis der Kanaren-Flora (Gramineae). Cuad. Bot. Canar. 28: 3-9.

SCHOLZ, H. \& M. RISTOW -2005- Neue
Nachrichten über die Gattung Eragrostis (Gramineae) in Mitteleuropa. Verh. Bot. Ver. Berlin Brandenburg 138: 15-29.

SERRA LALIGA, J., X. SOLER \& G. MATEO SANZ -1993- Fragmenta chorologica occidentale 4685. Anales Jard. Bot. Madrid 51(1): 136.

SIERRA I RÀFOLS, E. -1979- Algunes espècies adventícies i naturalitzades. Collect. Bot. 11: 297-300.

SILVESTRE, S. -2004- Ipomoea triloba L. (Convolvulaceae) una nueva especie alóctona para la península.'Lagascalia '24: 63 -66.

SNOW, N. -1998- Nomenclatural changes in Leptochloa P. Beauvois sensu lato (Poaceae, Chloridoideae). Novon 8: 77-80.

SOBRINO, E. \& J.P. DEL MONTE -1992- Sobre las especies Solanum sarrachoides Sendt. y Solanum physalifolium Rusby var. nitidibaccatum (Bitter) Edmonds: ecología y distribución en España. Anales Jard. Bot. Madrid 50: 119-121.

STRONG, M.T. \& W.L. WARGNER -1997-New and noteworthy Cyperaceae from the Hawaiian Islands. Bishop Museum Occasional Papers 48: 37 -50.

TANJI, A. \& A. TALEB -1997- New weed species recently introduced into Morocco Weed Research 37(1): 27-31.

TORRELLA, F., R.M. MASALLES \& J.M. CAMARASA -1974- Dues localitats catalanes de Cenchrus incertus M.A. Curtis, gramínia nova per a la Península Ibèrica. Butll. Inst. Catalana Hist. Nat. 38 (Secc. Bot. 1): 37-41.

TUTIN, T.G. -1976-Bidens. In: Tutin, T.G. et al. (eds.), Flora Europaea, vol. 4. Cambridge University Press, Cambridge: 139-140.

UOTILA, P. -1990- Chenopodium. In: Castroviejo, S. et al. (eds.), Flora Iberica, vol. II: Platanaceae-Plumbaginaceae (partim). Real Jardín Botánico, CSIC, Madrid: 484500 .

UOTILA, P. -2001-Chenopodium. In: Jonsell, B. (ed.), Flora Nordica, vol. II: Chenopodiaceae to Fumariaceae. The Bergius Foundation, Stockholm: 4-31.

URIBE-ECHEBARRÍA, P.M. -2003- Galinsoga. In: Aizpuru, I. et al. (eds.), Claves Ilustradas de la Flora del Pais Vasco y territorios 
limitrofes. Eusko Jaurlaritza-Gobierno Vasco. VALDÉS, B., S. TALAVERA \& E. FERNÁNDEZ-GALIANO (eds.) -1987Flora vascular de Andalucia occidental. II. Ketres Editora, Barcelona: 640 p.

VALDÉS, B., V. GIRÓN, E. SÁNCHEZ GULLÓN \& I. CARMONA -2007-Catálogo florístico del espacio natural de Doñana (SO de España). Plantas vasculares. Lagascalia 27: 73-362.

VALLVERDÚ, S. -2000- Chloris virgata (Gramineae), alóctona nueva para la Península Ibérica. Anales Jard. Bot. Madrid 57: 429-430

VÁZQUEZ, F.M. -1998- Elymus elongatus subsp. ponticum (sic!) (Gramineae) en la Península Ibérica. Anales Jard. Bot. Madrid 57(1): 176-178.

VERLOOVE, F. -1998- Malvastrum americanum en Malvastrum coromandelianum (Malvaceae) nieuw voor de Belgische adventief-flora (Malvastrum americanum and Malvastrum coromandelianum (Malvaceae) new for the Belgian adventitious flora). Dumortiera 69: 1315.

VERLOOVE, F. -2003- Physalis ixocarpa Brot. ex Hornem. and Verbena litoralis Kunth, new Spanish xenophytes and records of other interesting alien vascular plants in Catalonia (Spain). Lazaroa 24: 7-11.

VERLOOVE, F. $-2005 a-$ New records of interesting xenophytes in Spain. Lazaroa 26: 141-148.

VERLOOVE, F. -2005b- A synopsis of Jarava Ruiz \& Pav. and Nasella E. Desv. (Stipa L. s.1.) (Poaceae: Stipeae) in southwestern Europe. Candollea 60(1): 97-117.

VERLOOVE, F. -2006-Catalogue of neophytes in Belgium (1800-2005). Scripta Botanica Belgica 39: 89 p.

VERLOOVE, F. -2008a- Studies within the genus Digitaria Haller (Poaceae: Panicoideae) in southwestern Europe. Candollea (submitted).

VERLOOVE, F. -2008b-Galenia secunda. Corrections et commentaires apportés aux exsiccata distribués dans les fascicules précédents. Soc. Ech. Pl. Vasc. Eur. Bass. Médit., Bull. 30 (submitted).

VERLOOVE, F. \& C. VANDENBERGHE 1993- Nieuwe en interessante graanadventieven voor de Noordvlaamse en Noordfranse flora, hoofdzakelijk in 1992 (New and interesting grain-aliens in Northern Flanders and Northern France, especially in 1992). Dumortiera 53-54: 35 -57.

VERLOOVE, F. \& C. VANDENBERGHE 1994- Nieuwe en interessante graan- en veevoederadventieven voor de Belgische en Noordfranse flora, hoofdzakelijk in 1993 (New and interesting grain- and cattle fodder aliens in Belgium and northern France, especially in 1993). Dumortiera 58-59: 4459.

VERLOOVE, F. \& C. VANDENBERGHE 2002-Quelques xénophytes intéressantes ou nouvelles du midi de la France (départements des Pyrénées-Orientales et de l'Hérault) et de l'Espagne limitrophe. Le Monde des Plantes 477: 12-13.

WALTERS, S.M., A. BRADY, C.D. BRICKELL, J. CULLEN, P.S. GREEN, J. LEWIS, V.A MATTHEWS, D.A WEBB, P.F. YEO \& J.C.M. ALEXANDER (eds.) -1984- The European Garden Flora. Volume 2 (part II). Cambridge University Press: 318 p.

WIPFF, J.K. -2003-Melinis. In: Barkworth, M.E. et al. (eds.), Flora of North America north of Mexico, vol. 25. Oxford University Press, New York-Oxford: 490-492.

ZIZKA, G. -1988- Revision der Melinideae Hitchcock (Poaceae, Panicoideae). Bibliotheca Botanica 138: 1-149 p. 